\title{
CAMBIAL PHENOLOGY INFORMS TREE-RING ANALYSIS OF FIRE SEASONALITY IN COASTAL PLAIN PINE SAVANNAS
}

\author{
Monica T. Rother ${ }^{*}$, Jean M. Huffman², Grant L. Harley ${ }^{3}$, William J. Platt ${ }^{2}$, \\ Neil Jones ${ }^{2}$, Kevin M. Robertson ${ }^{1}$, and Steve L. Orzell ${ }^{4}$ \\ ${ }^{1}$ Tall Timbers Research Station, \\ 13093 Henry Beadel Drive, Tallahassee, Florida 32312, USA \\ ${ }^{2}$ Department of Biological Sciences, Louisiana State University, \\ 202 Life Science Building, Baton Rouge, Louisiana 70803, USA \\ ${ }^{3}$ Department of Geography, University of Idaho, \\ 875 Perimeter Drive, Moscow, Idaho 83844, USA \\ ${ }^{4}$ Avon Park Air Force Range, \\ 29 South Boulevard, Avon Park, Florida 33825, USA \\ *Corresponding author: Tel.: +1-541-908-2068; e-mail: rotherm@uncw.edu
}

\begin{abstract}
Understanding of historical fire seasonality should facilitate development of concepts regarding fire as an ecological and evolutionary process. In tree-ring based fire-history studies, the seasonality of fire scars can be classified based on the position of the fire scar within or between growth rings. Cambial phenology studies are needed to precisely relate a fire-scar position to months within a year because the timing of dormancy, earlywood production, and latewood production varies by species and location. We examined cambial phenology patterns of longleaf pine (Pinus palustris Mill.), slash pine (P. elliottii Engelm.), and South Florida slash pine (P. densa [Little \& K.W. Dorman] Silba) at sites in southern Georgia and south-central and northern Florida, USA. We developed long-term (2.5 yr to $12 \mathrm{yr}$ ) datasets of monthly growth and dor-
\end{abstract}

\section{RESUMEN}

El entendimiento de la estacionalidad histórica de los incendios debería facilitar el desarrollo de conceptos relacionados con el fuego como un proceso ecológico y evolutivo. En los estudios de historia de incendios basados en anillos de crecimiento, la estacionalidad de las cicatrices de fuego puede ser clasificada basada en la posición de la cicatriz dentro o entre anillos de crecimiento. Los estudios fenológicos del cambium son necesarios para relacionar de manera precisa la posición de una cicatriz con los meses dentro de un año, dado que el período de dormición, y la producción de leño temprano y tardío varía por especies y ubicación geográfica. Examinamos en este trabajo los patrones fenológicos del cambium del pino de hoja larga (Pinus palustris Mill.), del pino ellioti ( $P$. elliottii Engelm.), y del pino ellioti variedad densa (o South Florida slash pine; $P$. densa [Little \& K.W. Dorman] Silba) en sitios en el sur de Georgia y centro-sur y norte de Florida, EEUU. Desarrollamos bases de datos de crecimiento y dormición mensuales a largo 
mancy and determined when trees transitioned from producing earlywood to producing latewood each year. Most trees were dormant for a period of 1 to 2 months in the winter and transitioned from earlywood to latewood in June. Given the annual growth ring morphology of the pines that we studied and the timing of the lightning-fire season in our study area, we propose a new classification system for assigning seasonality to fire scars found in the three native upland pine species that we studied. This new system, which we name the Coastal Plain Pine System, accounts for the large proportion of latewood typical of these pines and includes a position (the transition position) that corresponds with the time of year when lightning fires occur most frequently. Our findings demonstrate how cambial phenology data can improve interpretation of fire-scar data for determining historical fire seasonality. plazo (de 2.5 años a 12 años) y determinamos cuándo los árboles producían en cada año la transición entre leño temprano y tardío. La mayoría de los árboles permanecieron en dormición por un período de 1 a 2 meses durante el invierno, y produjeron la transición desde leño temprano a tardío en junio. Dada la morfología del crecimiento anual de los anillos de los pinos estudiados y el período de tormentas eléctricas con rayos que provocan incendios en nuestra área de estudio, proponemos un nuevo sistema de clasificación para asignar la estacionalidad a las cicatrices de los tres pinos de altura estudiados. Este nuevo sistema, que 1lamamos sistema de pinos costeros de llanura, da cuenta de la mayor proporción del leño tardío típico de esos pinos e incluye una posición (llamada de transición) que se corresponde con el período del año cuando los incendios por rayos ocurren con mayor frecuencia. Nuestros resultados demuestran cómo los datos de la fenología del cambium pueden mejorar la interpretación de los datos de cicatrices de fuego para determinar la estacionalidad histórica de los incendios.

Keywords: cambial phenology, dendrometer bands, fire regimes, fire scars, fire seasonality, longleaf pine, North American Coastal Plain, pine savannas, Pinus elliottii, Pinus palustris

Citation: Rother, M.T., J.M Huffman, G.L Harley, W.J Platt, N. Jones, K.M. Robertson, and S.L. Orzell. 2018. Cambial phenology informs tree-ring analysis of fire seasonality in Coastal Plain pine savannas. Fire Ecology 14(1): 164-185. doi: 10.4996/fireecology.140116418

\section{INTRODUCTION}

In many pyrogenic forests, woodlands, and savannas worldwide, uncertainty surrounds the seasonality of past fire regimes. In some areas and time periods, lightning ignitions may have concentrated fires in months characterized by high cloud-to-ground lightning activity and flammable fuel conditions, while in other times and locations, anthropogenic fires both within and outside of the lightning-fire season may have been more common. Understanding of historical fire seasonality should facilitate development of concepts regarding fire as an evolutionary and ecological process (Pausas and Schwilk 2012, Pausas et al. 2017). Such understanding also should help to interpret the roles of anthropogenic and lightning fire, topics of intense interest and debate in North America and globally (Slocum et al. 2007, Bowman et al. 2009, Whitlock et al. 2010, Bowman et al. 2011, Platt et al. 2015, Benali et al. 2017). Further, understanding of historical fire seasonality can provide important context for ecologically relevant land management decisions and, when practical, can guide 
ecological fire management on modern landscapes (Hayward et al. 2012, Ryan et al. 2013, Fill et al. 2015, Platt et al. 2015).

Fire scars in annual growth rings of trees can provide direct evidence of historical fire seasonality, especially in ecosystems characterized by a frequent, low-severity fire regime. The season of fire scars is classified based on the location of the fire scar within an annual ring. In conifers growing in temperate and subtropical climates, a year of annual growth includes: 1) a period of earlywood formation during which tracheid cells have relatively large lumen areas and thin cell walls; 2) a subsequent period of latewood formation during which tracheid cells have smaller lumen and are thicker walled; and 3) a dormant period when tracheid cells are not produced (Fritts 1976). In the most commonly used system for classifying seasonality among dendrochronologists, each fire scar is assigned to one of five possible positions, specifically three in the earlywood zone, one in the latewood zone, and one between annual rings (i.e., the dormant period). This system (hereafter, the classic seasonality system) was developed from studies of conifers of the western United States, especially ponderosa pine (Pinus ponderosa Lawson \& C. Lawson; Ahlstrand 1980, Dieterich and Swetnam 1984, Baisan and Swetnam 1990, Caprio and Swetnam 1995, Grissino-Mayer et al. 2004) and has been used widely in other temperate ecosystems (e.g., Stephens et al. 2003, Fulé et al. 2007, Sakulich and Taylor 2007).

To precisely relate a fire-scar location to a certain time of year, information is needed on the timing of dormancy, earlywood, and latewood production for trees in a given study area. This timing differs with species, photoperiod, and climate (Fritts 1976, Vaganov et al. 2006). Fire-scar positions within annual rings from different regions may equate to notably different times of year. For example, an early study of longleaf pine in Florida indicated a dormant period of approximately 2 months (Langdon 1963), but the dormant peri- od may exceed half a year or more in length for conifers growing at higher latitudes and elevations (Daubenmire 1950, Fritts 1976). More studies that examine cambial phenology (e.g., Harley et al. 2012) or compare fire-scar position to known fire-injury dates (e.g., Stephens et al. 2018) should improve the usefulness of fire-scar data for assessing historical fire seasonality.

The typical morphology of annual growth rings of different species can vary, and these differences should be considered when classifying the seasonality of fire scars. For example, common pines of the North American Coastal Plain including longleaf pine (Pinus palustris Mill.), slash pine ( $P$. elliottii Engelm.), South Florida slash pine ( $P$. densa [Little \& K.W. Dorman] Silba), shortleaf pine ( $P$. echinata Mill.), and loblolly pine (P. taeda L.) (nomenclature from Weakley 2015), are characterized by annual growth rings that are morphologically distinct from other conifers. South Florida slash pine has been treated as a variety of slash pine, but recent phylogenetic studies failed to show a relationship with $P$. elliottii (Weakley 2015). These species of pine often produce a high proportion of latewood relative to earlywood each year, resulting in high-density wood. This is especially true of longleaf pine and slash pine, which have higher specific gravities than any other pine species in the USA (Miles and Smith 2009). In contrast, the species used to develop the classic seasonality system (Ahlstrand 1980, Dieterich and Swetnam 1984, Baisan and Swetnam 1990, Caprio and Swetnam 1995, Grissino-Mayer et al. 2004), including ponderosa pine, generally produce a lower proportion of latewood each year (Figure 1; Schweingruber 1993). Given these dissimilarities along with considerations about the timing of lightning fires, some fire-history studies in the North American Coastal Plain have relied on alternative systems for classifying fire scar seasonality (e.g., Huffman et al. 2004, Huffman 2006, White and Harley 2016). 


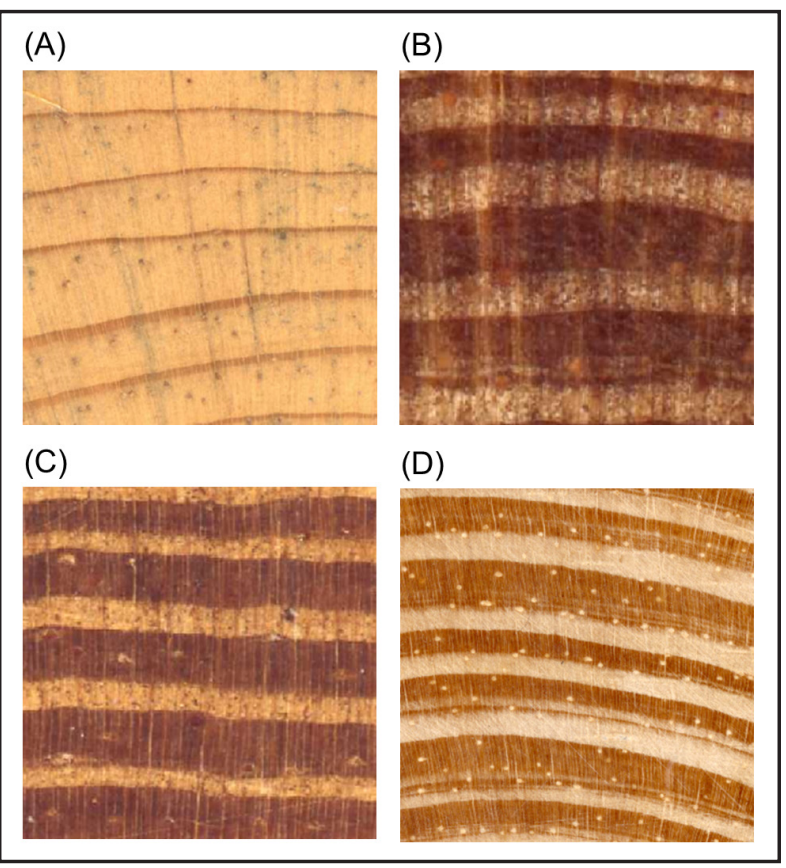

Figure 1. Tree-ring photographs of four species of pine (Pinus): A) ponderosa pine (P. ponderosa), B) longleaf pine (P. palustris), C) slash pine (P. elliottii), and D) South Florida slash pine (P. densa). Although ring characteristics vary within a given species and individual tree, the proportion of latewood in longleaf, slash, and South Florida slash pine is typically higher than in ponderosa pine and many other species found in the western USA. Sample collector and location: A) M. Rother, Zuni Mountains, New Mexico; B) Jean Huffman, St. Joseph Bay State Buffer Preserve, Florida; C) Jean Huffman, Little St. George Island, Florida; and D) G. Harley, No Name Key, Lower Florida Keys, Florida.

In our study, we focused on improving the interpretation of fire seasonality from fire-scar data. We conducted a multi-year study of cambial phenology patterns of live trees for three pine species in pine savannas of Florida and southern Georgia, within the North American Coastal Plain. Our specific research objectives were to: 1) determine the seasonal timing of dormancy, earlywood production, earlywood-latewood transition, and latewood production within annual rings; 2) determine how different cambial phenology phases relate to fire climate (i.e., cloud-to-ground lightning activity and climatic conditions conducive to fire spread) and records of lightning fires; and 3) present a system for classifying fire scar seasonality that considers both the timing of the lightning-fire season and the morphology of the annual rings of the pine species that we studied. Previously, limited understanding of cambial growth patterns in the most common pine species in the North American Coastal Plain made it difficult to precisely assess historical fire seasonality (but see: Paul and Marts 1931, Langdon 1963, Harley et al. 2012). Our study aimed to enable more informed interpretations of the seasonal timing of fires using fire-scar positions within annual growth rings.

\section{METHODS}

\section{Study Areas}

We conducted our study in Florida and southern Georgia within the North American Coastal Plain, USA. Fire-frequented pine savannas and woodlands (sensu Platt 1999, Fill et al. 2015) were, historically, the most widespread upland habitat in this region. Pine trees formed incomplete, often relatively open canopies above a graminoid dominated ground layer of vegetation (Platt 1999). The ground layer vegetation was species rich (Orzell and Bridges 2006, Platt et al. 2006) and consisted of a diverse array of often endemic perennial warm-season grasses, forbs, and shrubs (Noss et al. 2015). Historically, these savannas burned frequently during fires ignited by lightning during the fire season (sensu Platt et al. 2015). Additionally, Native Americans and early European settlers ignited and manipulated fires, as occurred in many parts of North America (Pyne 1982, Stambaugh et al. 2018). The relative contribution of human and lightning ignitions across space and time in the region remains unclear. Over the past circa 200 years, widespread loss of pine savannas has occurred due to anthropogenic activities including extensive fragmentation of landscapes, as well as conversion to agricultural land, pine 
plantations, improved pasture, fire-excluded forest, and urban development. These pine savannas are now restricted to $<4 \%$ of their original distribution (Noss et al. 2015).

Our study involved monitoring cambial growth patterns of three pine species: longleaf pine, slash pine, and South Florida slash pine. These pines are the dominant canopy trees in the pyrogenic savannas and woodlands of the North American Coastal Plain. Historically, longleaf pine, a tree whose needles become flammable once cast (Fonda 2001, Platt et al. 2016), was the dominant or co-dominant tree on about $85 \%$ of the uplands of the region (approximately 51 million hectares, Frost 2006). Longleaf pine ranged from Virginia south to Florida and west to eastern Texas (Weakley 2015). South Florida slash pine is often the dominant tree in southern Florida, and can occur intermixed with longleaf pine in south-central peninsular Florida. Slash pine typically occurred in wetter sites within the longleaf pine matrix and occurred from eastern South Carolina to northern peninsular Florida and west to eastern Louisiana (Weakley 2015); however, it has been widely planted outside this range.

We used three study areas: Avon Park Air Force Range in south-central Florida (hereaf-

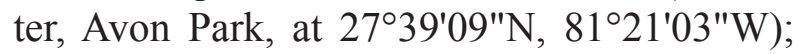
the St. Joseph Bay State Buffer Preserve in the panhandle of western Florida (hereafter, Buffer Preserve, at $29^{\circ} 42^{\prime} 4^{\prime \prime} \mathrm{N}, 85^{\circ} 17^{\prime} 40^{\prime \prime} \mathrm{W}$ ); and a private property in southwestern Georgia known as the Wade Tract (hereafter, Wade Tract, at $30^{\circ} 45^{\prime} 49^{\prime \prime} \mathrm{N}, 83^{\circ} 59^{\prime} 53^{\prime \prime} \mathrm{W}$ ) (Figure 2). At Avon Park, we sampled six sites along a gradient of moisture availability, including two dry sites (sandhills and scrubby flatwoods), two mesic sites (cutthroat flatwoods), and two hydric sites (wet flatwoods). At Buffer Preserve, we stratified sampling based on two levels of moisture availability: a dry site (scrubby flatwoods) and a mesic site (mesic flatwoods). Finally, at Wade Tract, we sampled one site in an upland pine savanna woodland, the domi- nant community type at that study area. Terminology for and description of community types are from the Florida Natural Areas Inventory (2010). We sampled approximately equal numbers of longleaf pine and South Florida slash pine at Avon Park, approximately equal numbers of longleaf and slash pine at Buffer Preserve, and only longleaf pine at Wade Tract. Because patterns of tree-ring growth may be influenced by tree size, we sampled pines across a range of tree sizes, based on diameter at breast height (DBH): Avon Park, $6 \mathrm{~cm}$ to $45 \mathrm{~cm}$; Buffer Preserve, 5 $\mathrm{cm}$ to $41 \mathrm{~cm}$; and Wade Tract, $10 \mathrm{~cm}$ to $87 \mathrm{~cm}$.

\section{Punch Core Data: Determining Earlywood-Latewood Transition}

To determine the timing of when pine trees in our study areas transition from production of earlywood to latewood, we collected short-increment cores (hereafter, punch cores, typically $1 \mathrm{~cm}$ to $2 \mathrm{~cm}$ in length) from all three study areas, using an increment hammer. At Avon Park sites, we collected punch cores each growing season from 2006 to 2008 from 72 trees (longleaf pine and South Florida slash pine), divided relatively evenly among dry, mesic, and hydric sites. At Buffer Preserve, we collected punch cores from 30 to 58 trees (longleaf pine and slash pine), depending on year, in 2006, 2012, and 2017, divided relatively evenly among dry and mesic sites. Finally, at Wade Tract, we collected punch cores from 12 longleaf pines, in the growing season of 2017. At all three study areas, sampling occurred every 2 to 4 weeks beginning in late spring until most or all of the sampled trees were producing latewood. We collected 1 to 2 punch cores from each tree, at approximately one meter aboveground. We mounted punch cores on wooden core mounts and sanded them with progressively fine sandpaper to improve the visibility of the tree rings (Stokes and Smiley 1968, Speer 2010). 


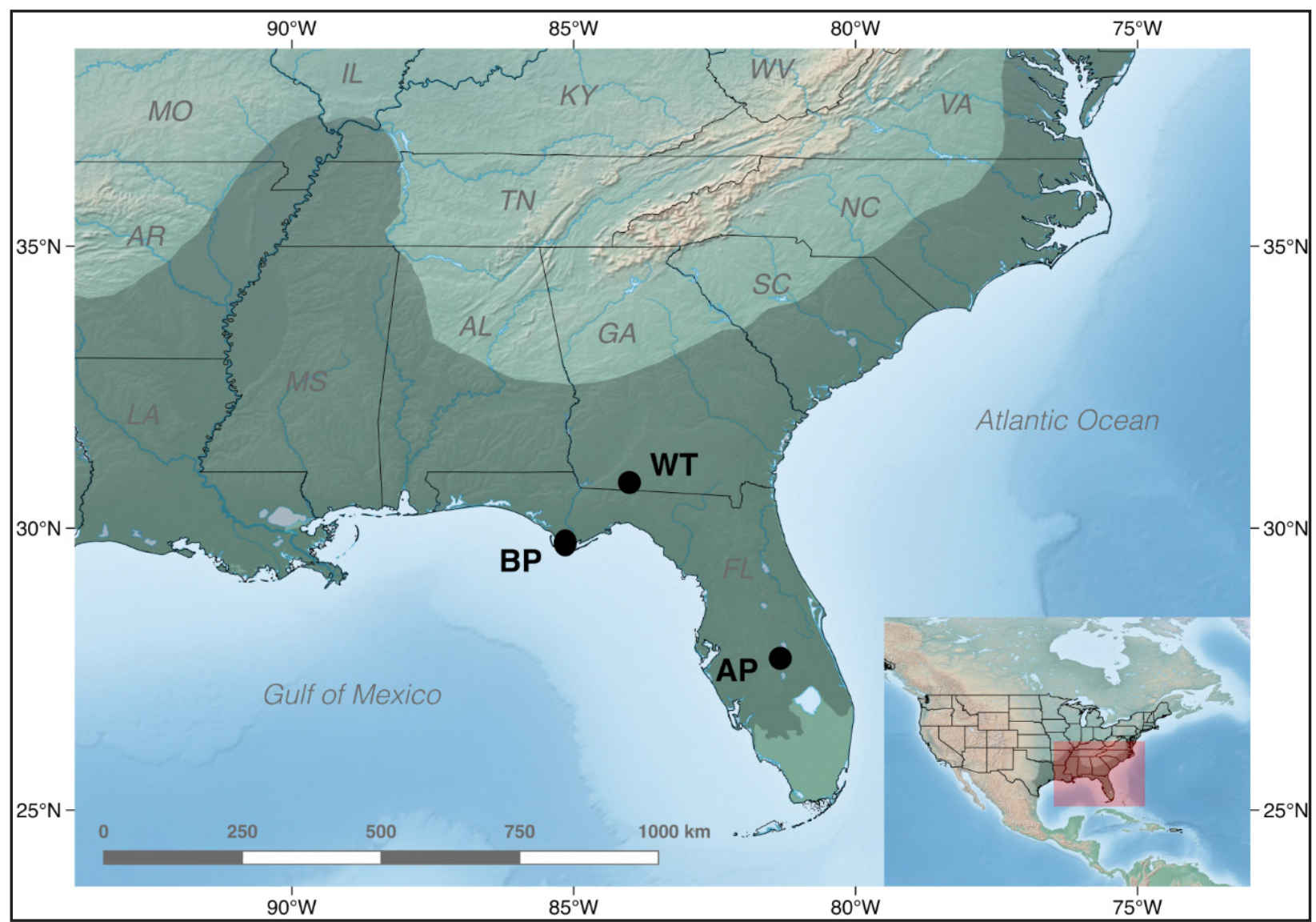

Figure 2. Map showing the three study areas in the southeastern US: Wade Tract (WT) in southern Georgia; St. Joseph Bay State Buffer Preserve (BP) in the panhandle of Florida; and Avon Park Air Force Range (AP) in south-central Florida. The dark green area shows the floristic province of the North American Coastal Plain and is adapted from Thorne (1993), Sorrie and Weakley (2001), and Noss et al. (2015). USA states on the map are abbreviated as following: $\mathrm{FL}=$ Florida, $\mathrm{GA}=$ Georgia, $\mathrm{AL}=\mathrm{Alabama}, \mathrm{MS}=$ Mississippi, LA = Louisiana, $\mathrm{AR}=$ Arkansas, $\mathrm{MO}=$ Missouri, $\mathrm{IL}=$ Illinois, $\mathrm{TN}=$ Tennessee, $\mathrm{KY}=\mathrm{Ken}-$ tucky, $\mathrm{WV}=$ West Virginia, $\mathrm{VA}=$ Virginia, $\mathrm{NC}=$ North Carolina, $\mathrm{SC}=$ South Carolina .

We analyzed punch cores to determine the timing of transition from earlywood to latewood. We examined each punch core under a high-magnification microscope (at $10 \times$ to $40 \times$ magnification) to determine whether the most recently produced tracheid cells were earlywood (i.e., larger, thinner walled cells) or latewood (smaller, thicker walled cells). Overly suppressed growth or poor sample quality occurred in $<5 \%$ of collected punch cores; these samples were not used. For each year at each study area, we determined which trees transitioned between each collection period. Trees were considered to have transitioned during a given time window (between date $x$ and date $y$ ) if the punch cores showed earlywood at date $x$ and then latewood at date $y$. Occasionally, replicate cores from the same tree and same sample date did not match in terms of most recent production of earlywood versus latewood, which is consistent with expected variability in growth patterns around a tree bole (Fritts 1976, Speer 2010). In these cases, we used the earliest date of latewood production as the end date of the transition period. After determining when individual trees transitioned between earlywood and latewood, we calculated the percentage of all trees that transitioned be- 
tween sample dates for each year at each study area. If $>75 \%$ of trees transitioned between two subsequent sample dates, then we defined the transition period as the month in which the midpoint between the two sampling dates fell. If $<75 \%$ of trees transitioned between two subsequent sample dates (which was the case in two of the seven combinations of study area and year), then three subsequent sampling dates were used and the transition period was defined as the month containing the midpoint between the earliest and latest dates.

\section{Dendrometer Band Data: Determining Timing of Growth and Dormancy}

We monitored tree stem growth patterns for pine trees at Avon Park and Buffer Preserve. We used dendrometer bands, which are metal bands placed around tree trunks that expand as the tree grows. As with the punch core data, we collected dendrometer data across varying community types and tree sizes. We installed dendrometer bands on 216 trees (longleaf pine, South Florida slash pine) at Avon Park, and on 60 trees (longleaf pine, slash pine) at Buffer Preserve. Prior to installing the bands, a rasp was used to remove loose bark. We took measurements of circumference to the nearest $0.1 \mathrm{~mm}$ approximately every month for 12 years at Buffer Preserve (Sep 2004 to Jun 2016) and for 2.5 years at Avon Park (Jan 2006 to Jul 2008). Sample sizes decreased slightly over time (three trees died at Buffer Preserve and nine at Avon Park, mostly from lightning strikes). Additionally, relatively intense prescribed fires occasionally destroyed dendrometer band springs, disrupting measurements for particular trees for one or more months until replacement bands were installed. The use and precision of dendrometer bands for monitoring tree stem growth has been reviewed elsewhere (Auchmoody 1976, Clark et al. 2000, Keeland and Young 2014). We did not monitor or account for diel variations in tree circumference (shrink-swell cy- cles related to water status), but these fluctuations are typically small and are not problematic for most studies of tree growth patterns (Herrmann et al. 2016). Our interest was in understanding what time of year corresponds with the boundary between annual growth rings and, for this purpose, our monthly data and our definition of dormancy was sufficient.

We used the dendrometer band measurements to estimate monthly growth of all sampled pine trees at each study area for the full sample period. We did not take measurements on the exact same day of each month, so the total amount of growth that occurred between two consecutive sample dates for each tree (e.g., 4 Jun 2010 and 3 Jul 2010) was split proportionately between the months (e.g., Jun and Jul). In each month of the year, there were at least a few trees that exhibited growth, so we defined dormant months as months in which most trees exhibited little or no growth (median growth $<0.2 \mathrm{~mm}$ ).

We examined whether nondormant pine trees during dormant months differed from all trees in the dataset in terms of tree size or species. We used chi-square goodness of fit tests to determine whether the distribution of nondormant trees among tree species and size categories was significantly different from that of all trees. The species categories were longleaf pine and South Florida slash pine at Avon Park and longleaf pine and slash pine at Buffer Preserve. The tree size classes were small $(<20$ $\mathrm{cm} \mathrm{DBH})$, medium $(\geq 20 \mathrm{~cm} \mathrm{DBH}$ to $30 \mathrm{~cm}$ $\mathrm{DBH})$, and large (>30 $\mathrm{cm} \mathrm{DBH})$.

\section{Proportion of Growth in Each Cambial Phenology Phase}

We calculated the average proportion of wood produced in each month at each study area and then associated months with cambial phenology phases (i.e., dormancy, earlywood production, earlywood-latewood transition, and latewood). First, we calculated the proportion of growth during dormant months (de- 
fined as months of median growth $<0.2 \mathrm{~mm}$ ). Next, we calculated the proportion of growth during the transition month (defined above). We then calculated the proportion of earlywood produced for months between dormancy and transition. The proportion of latewood produced was calculated for months between the transition month and the following dormant period.

\section{Climate, Lightning, and Lightning-Fire Data}

We examined climate, lightning, and lightning-fire data to determine which cambial phenology phase or phases corresponded with the lightning-fire season. We downloaded daily cloud-to-ground lightning flash (or strike) data from the National Lightning Detection Network for the period 1986 to 2013 for our counties of interest (Gulf County, Florida; Highlands County, Florida; and Thomas County, Georgia) and then calculated a daily mean number of flashes per month for each county. The Florida Forest Service provided lightning-fire data for a similar time period (1981 to 2016) and included the date and county for all lightning fires in Florida except those on federal and tribal lands. We used these data to calculate the total number of lightning fires and the total area burned per month during the entire period of record for each county of interest. We assessed monthly temperature and precipitation patterns using divisional data from the National Climatic Data Center (NCDC 2017). We graphed the monthly temperature, precipitation, cloud-to-ground lightning flashes, and lightning-fire occurrence together along with the typical timing of the various cambial phenology phases (i.e., dormancy, earlywood production, transition, latewood production) for each study area. Finally, we compared monthly temperature and precipitation data for the study period against the longterm climate record to determine whether sampled years were typical of long-term climate patterns.

\section{RESULTS}

\section{Punch Core Data: \\ Determining Earlywood-Latewood Transition}

Punch core data indicated that the earlywood-latewood transition for most pine trees occurred between late May and late June, regardless of study area, year, tree size, tree species, or habitat type (Figure 3). At each study area and in each year, the midpoint date for the transition period occurred in June. In three years at two study areas (Buffer Preserve in 2012, 2017; Wade Tract in 2017), a small percentage of trees ( $8 \%$ to $13 \%)$ transitioned before or after the sampling period.

\section{Dendrometer Band Data: Determining Timing of Radial Growth and Dormancy}

Dendrometer band data from both Avon Park and Buffer Preserve revealed similar patterns of dormancy and growth in the pine trees that we sampled. The general pattern was a dormant period (i.e., median growth $<0.2 \mathrm{~mm}$ ) in January at Avon Park, and in both January and February at Buffer Preserve (Figure 4). At both study areas, December through February were characterized by low median growth and some trees were dormant for this full threemonth period. At both study areas, March and April were months of rapid growth for most trees, followed by slower but continual growth through the summer and fall. Our large multiyear dataset did include some negative measurements, as indicated by values below zero (Figure 4). These resulted from either minor contraction in tree circumference due to weather (shrink-swell cycles) or limitations in the precision and accuracy of readings from dendrometer bands (Auchmoody 1976, Clark et al. 2000, Keeland and Young 2014, Herrmann et al. 2016). Some prescribed fires also resulted in needle scorch and suppressed growth of some trees during the study period. 


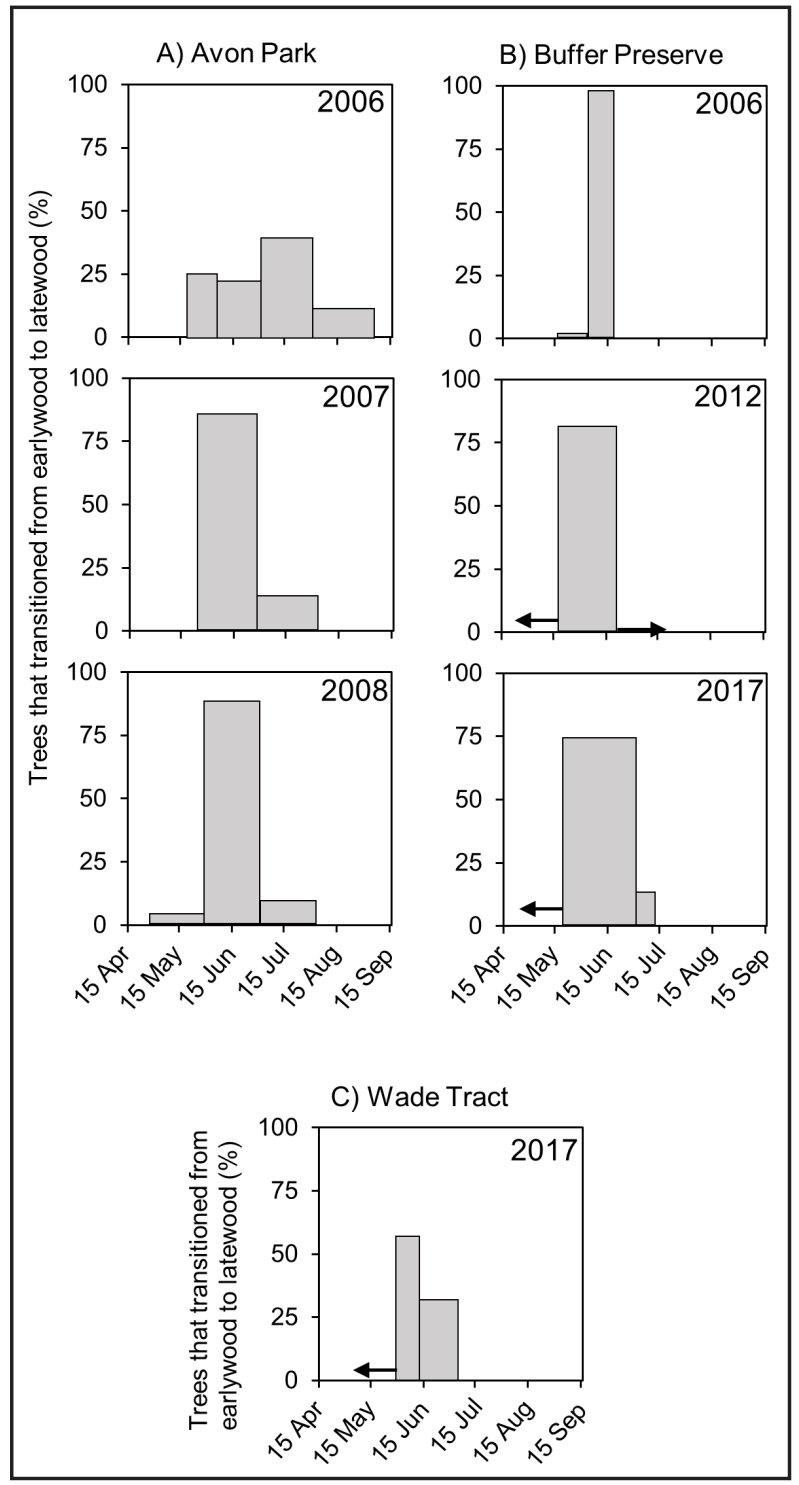

Figure 3. The percentage of trees that transitioned from earlywood production to latewood production between punch core sampling dates at: A) Avon Park, B) Buffer Preserve, and C) Wade Tract. Black arrows indicate the percentage of trees that transitioned sometime before or after the sampling period, if applicable.

Although most pine trees conformed to similar patterns of monthly tree growth and dormancy, we observed some differences between tree species and among tree size classes in the proportion of trees that continued to grow during the typical dormant period (Figure 5). With regard to tree species at Avon
Park, the observed proportion of longleaf pine compared to South Florida slash pine among trees that were not dormant in January (the dormant month) was different than expected $\left(\chi^{2}=9.6, P=0.002\right)$; a higher proportion than expected of longleaf pine were not dormant. At Buffer Preserve, a higher proportion than expected of trees that were not dormant were slash pine rather than longleaf pine in both January $\left(\chi^{2}=4.0, P=0.045\right)$ and February $\left(\chi^{2}\right.$ $=20.8, P \leq 0.001)$. In terms of tree size, the ratio of small, medium, and large trees observed was not different than expected at Avon Park for January $\left(\chi^{2}=3.9, P=0.145\right)$. Differences in size classes were significant at Buffer Preserve for both January $\left(\chi^{2}=85.9, P \leq\right.$ $0.001)$ and February $\left(\chi^{2}=129.7, P \leq 0.001\right)$, where small trees were more likely to grow during dormant months than expected.

\section{Cambial Phenology Phases}

The proportion of growth that occurred in each month and in each cambial phenology phase (i.e., dormant, earlywood, transition, and latewood) calculated from the dendrometer band data was similar for Avon Park and Buffer Preserve (Figure 6). With regard to earlywood and latewood production, we observed relatively even ratios of earlywood to latewood each year. Earlywood production was more rapid and occurred over a period of three to four months (Feb to May at Avon Park and Mar to May at Buffer Preserve). Latewood production occurred over a period of six months at both study areas (Jul to Dec), with growth slowing in the later months of this period. The transition between earlywood and latewood production in the pine species that we monitored is typically abrupt (Gaby 1985). Thus, the June transition month likely included earlywood and latewood production on either side of the transition for individual trees. 


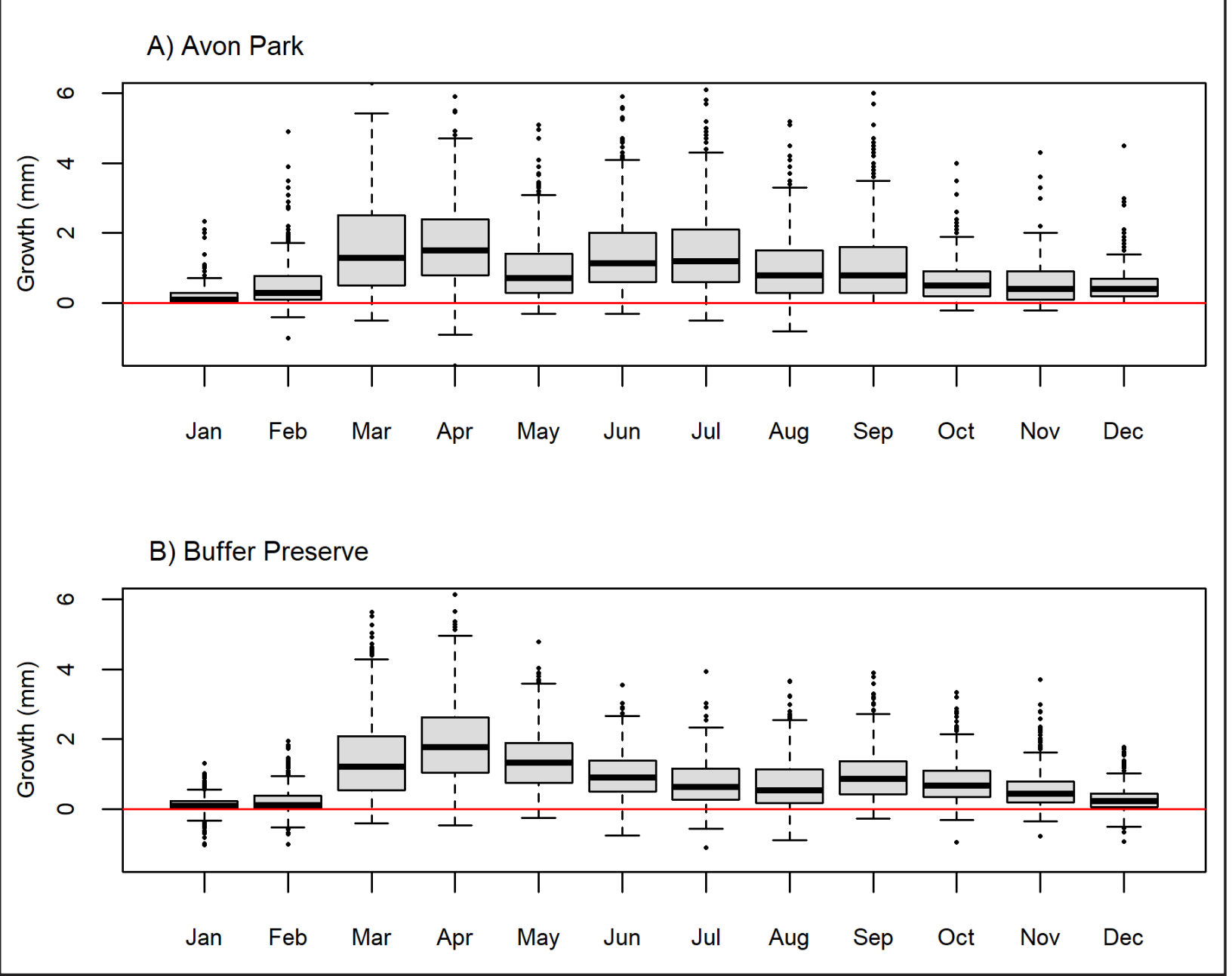

Figure 4. Monthly growth of pines at: A) Avon Park and B) Buffer Preserve, from dendrometer band data. At Avon Park, data are from 216 pines monitored over 2.5 years (Jan 2006 to Jul 2008). At Buffer Preserve, data are from 60 pines monitored over 12 years (Sep 2004 to Jun 2016). The thick black line inside the box indicates the median; the lines at the outer edges of the box indicate the upper and lower quartiles; and the lines at the end of the vertical dashed lines indicate the maximum and minimum values, excluding outliers, which are represented by dots. The red line indicates monthly growth of $0 \mathrm{~mm}$.

\section{The Lightning-Fire Season}

Each cambial phenology phase that we identified corresponded with differing environmental conditions that relate to the ignition and spread of fire (Figure 7). The earlywoodlatewood transition in June corresponded with frequent lightning fires, as did the surrounding months. At all three study areas, most fires (70\% to $75 \%$ ) occurred in May to July. Monthly patterns for total number of fires resembled monthly patterns for total area burned, statewide and for the counties of inter- est, except for Jefferson County, where relatively few fires occurred (Supplementary Figure 1). High average cloud-to-ground lightning flashes also occurred during and around the earlywood-latewood transition. In contrast, the dormant period (Jan or Jan to Feb, depending on study area) was characterized by virtually no lightning fires; only a few lightning fires (two to four per study area) occurred in those months for the entire period of record (1981 to 2016). The mean daily number of cloud-to-ground lightning flashes was also much lower during dormant months than in 


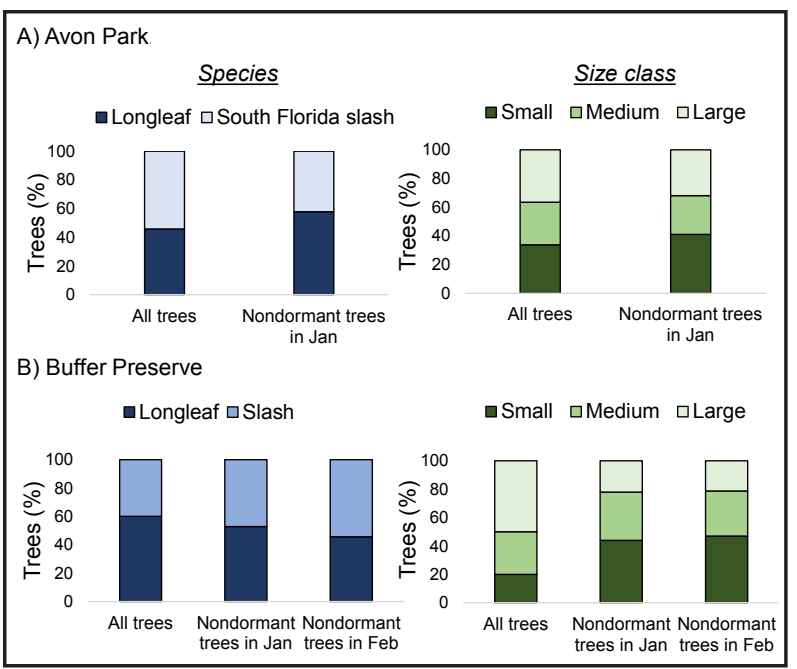

Figure 5. The proportion of trees of differing species and diameter size classes for all trees compared to only those trees that were not dormant in months identified as dormant. At Avon Park (A), only January was identified as a dormant month (median $<0.2 \mathrm{~mm}$ of growth) while at Buffer Preserve (B), January and February were identified as dormant months (median $<0.2 \mathrm{~mm}$ of growth).

the months surrounding the transition from earlywood to latewood (January and February ranged 2 to 6 flashes per day; May to July ranged 15 to 218 flashes per day). In terms of climate patterns, the time of year when lightning fires are most abundant occurred after a period of dryness (as indicated by relatively low amounts of precipitation in the two to five months preceding the earlywood-latewood transition).

\section{Sample Period Weather Compared to Long-Term Climate}

Our assessment of weather in the sample period (2006 to 2008 at Avon Park, 2004 to 2016 at Buffer Preserve, and 2017 at Wade Tract) revealed that weather in most months was typical of long-term patterns (1895 to 2016) in terms of monthly mean temperature and total monthly precipitation, with some exceptions (Supplementary Figures 2 and 3). Monthly mean temperatures were often warmer than the long-term average, sometimes exceeding one standard deviation from the mean. Although these much warmer temperatures occurred throughout the year, they were most common in summer months. With regard to precipitation, some months were exceptionally wet or dry, sometimes exceeding two standard deviations from the mean.

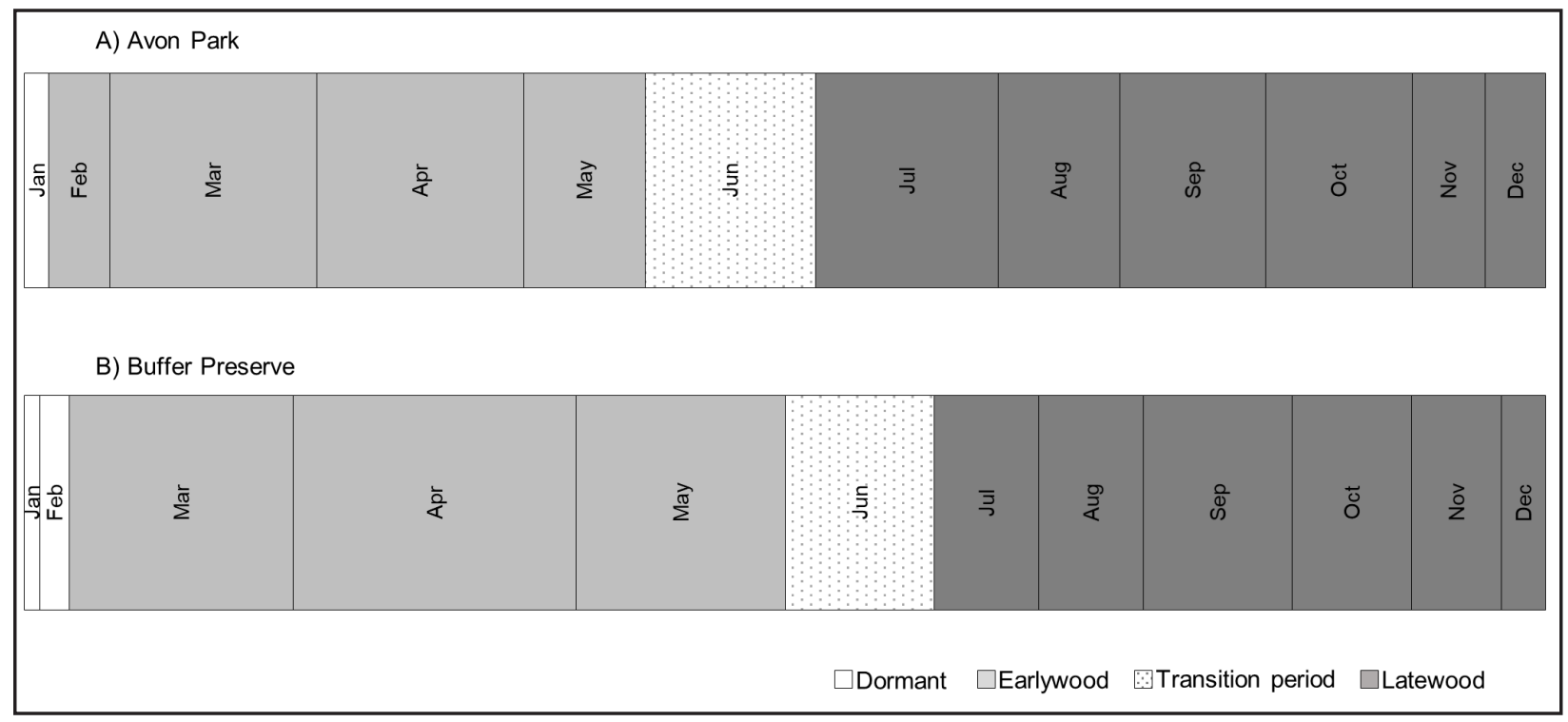

Figure 6. Mean proportion of total annual stem growth produced each month and corresponding cambial phenology phase (dormant, earlywood, earlywood-latewood transition, or latewood) at A) Avon Park and B) Buffer Preserve. 


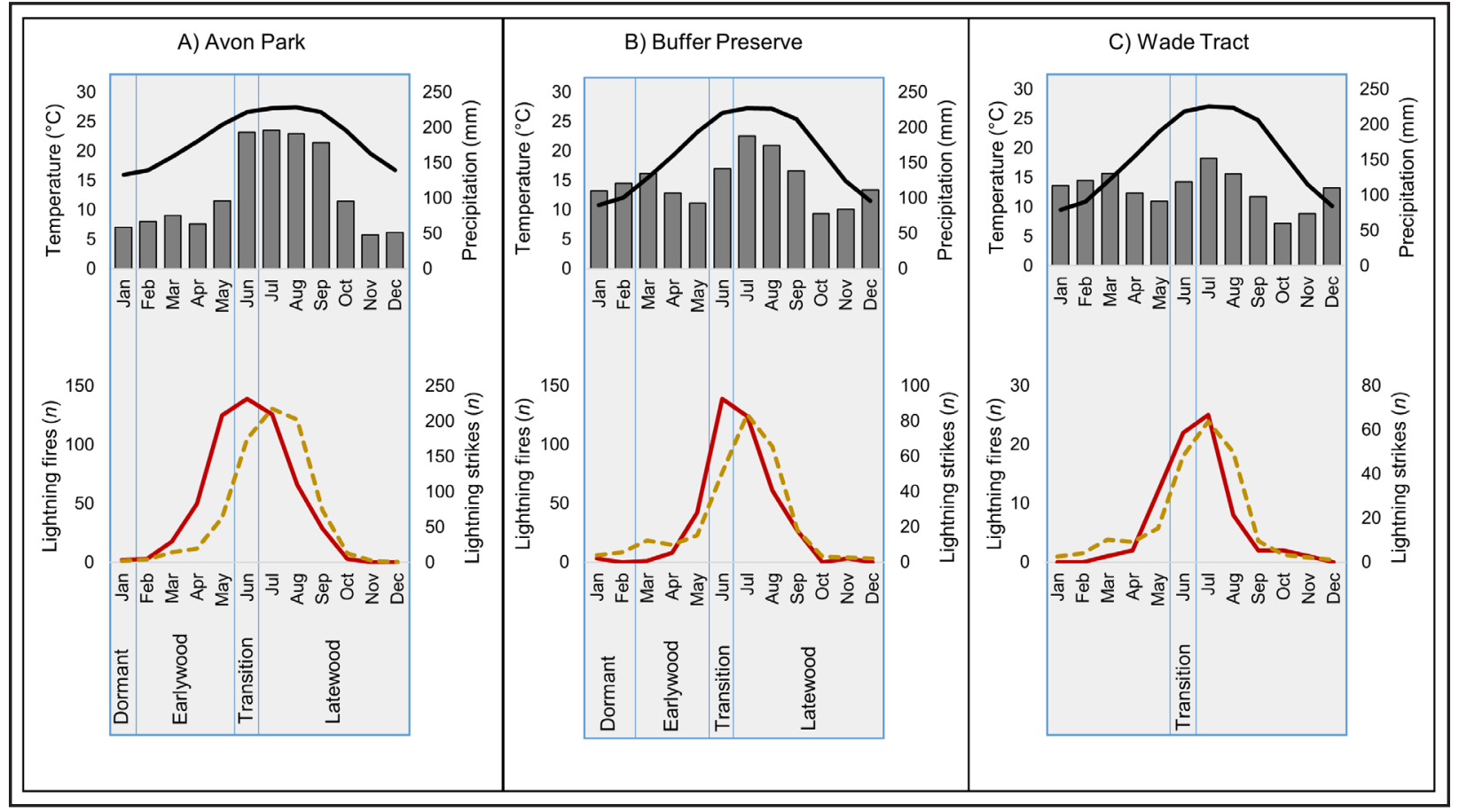

Figure 7. Patterns of climate, lightning fire, and lighting strikes for: A) Avon Park, B) Buffer Preserve, and C) Wade Tract. In the top panel for each study area, temperature and precipitation are plotted using Divisional Data from the National Climatic Data Center (NCDC 2017). Monthly mean temperature is shown as a black curve and monthly mean total precipitation is shown as gray bars. In the bottom panel for each study area, the red curve indicates total lightning fires per month $(n)$ documented by the Florida Forest Service for the county that contains each research study area for the period of record (1981 to 2016). Wade Tract is in Georgia (GA) approximately 16 kilometers north of the state border with Florida (FL), and in that case data from the nearest Florida county were used (Jefferson County). The yellow dashed curves indicate mean daily cloud-to-ground lightning flashes (or strikes) by month for the county that contains each research study area for the period of record (1986 to 2013). Note that precipitation in the top panel and lightning strikes in the bottom panel are plotted on a secondary $y$-axis.

\section{DISCUSSION}

We incorporate our findings regarding the cambial phenology of three pines found in the North American Coastal Plain and its relationship to lightning-fire patterns to present a modified system for classifying the seasonality of fire scars. Our new system, which we refer to as the Coastal Plain Pine System (Figure 8B), was developed using longleaf pine, slash pine, and South Florida slash pine. It is presented alongside the classic seasonality system (Figure 8A), developed from studies using conifers in the western USA (especially ponderosa pine). The Coastal Plain Pine System includes six fire-scar positions: 1) Dormant (D), for the position between the previous year's latewood and current year's earlywood; 2) Early Earlywood (EE), for the first half of earlywood; 3) Late Earlywood (LE), for the second half of earlywood; 4) Transition (T), for the area where trees change from producing earlywood to latewood; 5) Early Latewood (EL), for the first half of latewood; and 6) Late Latewood (LL), for the second half of latewood. Note that the Transition position consists of a few rows of cells because it is understood that this boundary is not always abrupt and that fire scars are often difficult to associate with a single row of cells. This system builds on earlier 


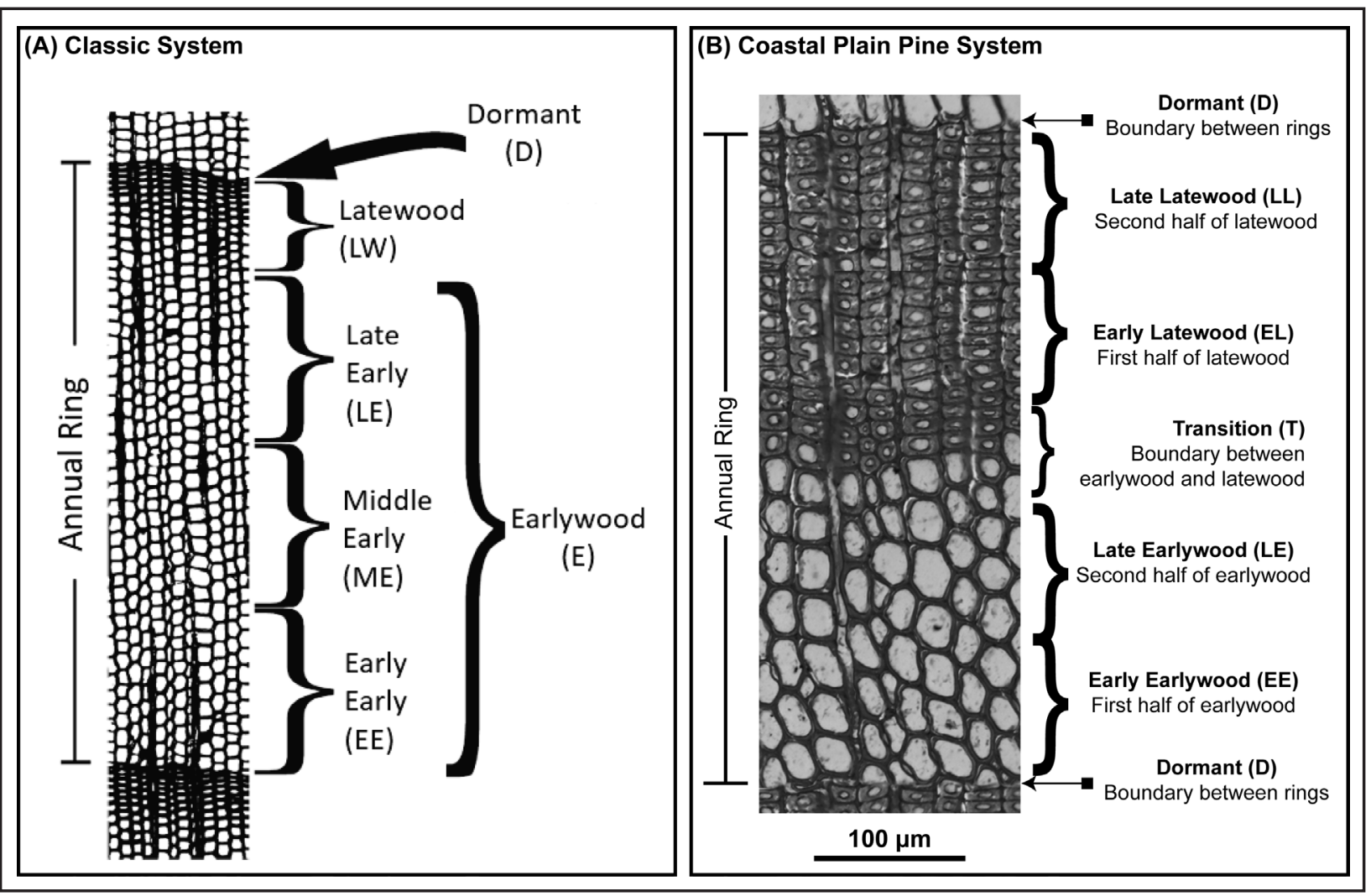

Figure 8. Classification systems for assigning seasonality to fire scars based on intra-annual ring position, including: A) the classic seasonality system, developed in the western USA (adapted from Caprio and Swetnam 1995); and B) our modified system, customized for longleaf pine (Pinus palustris), slash pine ( $P$. elliottii), and South Florida slash pine ( $P$. densa). In each panel, annual tree growth is from bottom to top. The growth ring used in our modified system is from a shallow micro-core of South Florida slash pine sampled in Harley et al. (2012).

efforts to adjust seasonal classification of fire scars to local needs (Huffman et al. 2004, Huffman 2006, White and Harley 2016) and will improve the accuracy and usefulness of fire-scar data for understanding historical fire regimes in pine savannas of the North American Coastal Plain. This work is timely given that few tree-ring based fire-history studies have been conducted in pine savannas of this region (but see: Huffman et al. 2004, Henderson 2006, Huffman 2006, Stambaugh et al. 2011, Harley et al. 2013, White and Harley 2016) and that more studies are anticipated following developments in field methodologies (Huffman and Rother 2017).

The Coastal Plain Pine System differs substantially from the classic seasonality system.
As seen in Figure 8, the Coastal Plain Pine System divides earlywood and latewood into two positions each, while the classic seasonality system divides earlywood into three positions and includes only one latewood position. This division of the ring in the Coastal Plain Pine System takes into account that the three pine species studied tend to have relatively high proportions of latewood in annual growth rings (Wahlenberg 1946, Miles and Smith 2009). In our study, almost half of total growth each year consisted of latewood. Latewood production also extended over a large portion of the year (approximately six months). In contrast, ponderosa pine is characterized by a much lower proportion of latewood formed over a shorter period of time 
(Fritts 1976, Schweingruber 1993). We acknowledge that ratios of earlywood to latewood vary even within individual trees, but these general patterns are notable. Another difference between the Coastal Plain Pine System and the classic seasonality system is that we have added a position at the transition between earlywood and latewood. Many pines found in the North American Coastal Plain, including longleaf and slash, are known to abruptly transition between earlywood and latewood (Gaby 1985), making the identification of scars at this location easier than for species that gradually transition. Previous studies in the North American Coastal Plain (e.g., Huffman et al. 2004, Huffman 2006, White and Harley 2016) have identified frequent scars at or near the earlywood-latewood transition, and our study demonstrates that, at least in Florida and southern Georgia, this position is important for understanding historical fire. We expect our system to be useful for future fire-history studies involving longleaf pine, slash pine, South Florida slash pine, and other tree species with a high proportion of latewood and an abrupt transition between earlywood and latewood.

We used our cambial phenology data to associate the six fire-scar positions with specific times of year. The monthly timing we present (Table 1) is based on data from longleaf, slash, and South Florida slash pines in Florida and southern Georgia, and is likely to be most accurate for studies within that region using those species. We expect that patterns may be similar for longleaf and slash pines found in other states within the North American Coastal Plain at similar latitudes (southern Alabama to southern Texas), although additional data should be obtained and used to adjust the timing. Because photoperiod and climate are known to influence cambial dormancy and earlywood-latewood transition (Fritts 1976, Vaganov et al. 2006), we expect that cambial phenology patterns for longleaf and slash pines growing at higher latitudes or elevations (e.g., slash pine in South Carolina, montane longleaf) will differ from those found in Florida and southern Georgia.

Although most pine trees followed the same pattern of dormancy and growth across our study areas throughout the period of study, we observed some variability in cambial phenology patterns. For this reason and others, it is important to note that the months we present (Table 1) are approximate. We found that at least some of the variability in cambial phenology patterns may be related to tree species or tree size. Additional variability may have resulted from sources of tree stress including needle scorch following prescribed fires, other injuries, and competition with neighboring trees, which we did not assess quantitatively. We also acknowledge that warmer tempera-

Table 1. Typical months corresponding with each of the fire-scar positions in the modified seasonality system for Avon Park, Buffer Preserve, and Wade Tract. Most cells are empty for the Wade Tract study area because no dendrometer band data were collected at that location.

\begin{tabular}{|c|c|c|c|}
\hline \multirow[b]{2}{*}{ Fire-scar position } & \multicolumn{3}{|c|}{ Approximate timing } \\
\hline & Avon Park, Florida & Buffer Preserve, Florida & Wade Tract, Georgia \\
\hline Dormant & Jan & Jan and Feb & \\
\hline Early earlywood & Feb to mid Apr & Mar to mid Apr & \\
\hline Late earlywood & Mid Apr to May & Mid Apr to May & \\
\hline Transition & Jun & Jun & Jun \\
\hline Early latewood & Jul to Sep & Jul to Sep & \\
\hline Late latewood & Oct to Dec & Oct to Dec & \\
\hline
\end{tabular}


tures during our study period compared to the long-term record create some uncertainty in using modern patterns to make inferences about the past. However, the close correspondence with our study findings to previous research in terms of when trees were dormant (Langdon 1963 Harley et al. 2012) and the consistency in growth and dormancy patterns across years of variable climate within our own dataset suggest that warmer temperatures in recent years are not yet resulting in significantly different cambial phenology patterns. Despite some variability and uncertainty, our results are striking in that they document similar cambial phenology patterns for three species of pine of varying size, sampled across more than three degrees of latitude. Analysis of fire-scar data should aim to identify general patterns of seasonality based on fire scars in many trees (e.g. Baisan and Swetnam 1990); for this objective, slight variability in cambial phenology patterns among trees or study years is not problematic.

Our findings should enable researchers who are working with fire-scar data to address key questions related to fire seasonality. A major contribution of our study is that it provides information needed to determine which historical fires in Florida and southern Georgia were associated with the lightning-fire season. The lightning-fire season and how it differs from anthropogenic fire seasons has been previously studied at Avon Park (Slocum et al. 2010, Slocum and Orzell 2013) and in the Florida Everglades (Slocum et al. 2007). These studies and others indicate that lightning fires are most likely to ignite and spread across the landscape at the ends of seasonally dry periods, when fine fuels typically contain little moisture and soil moisture or water levels are low in wetlands connecting uplands (Beckage et al. 2003, Platt et al. 2015). In the present study, lightning fires at our three study areas were found to occur in a similar narrow window of time associated with environmental conditions suitable to lightning-fire ignition and spread. This narrow window (the lightning-fire season) corresponds with three positions in the new Coastal Plain Pine System: Late Earlywood, Transition, and Early Latewood positions. Fire-scar records that document extensive fire activity outside the lightning-fire season are likely to indicate anthropogenic fires. Thus, seasonality of fires, as indicated by firescar position, should shed light on the relative contributions of lightning and anthropogenic fires to past fire regimes. Knowledge of the seasonality of past fire regimes may help fire managers understand fire regimes that led to the current landscapes that they manage and place current management decisions in a historical context.

\section{ACKNOWLEDGEMENTS}

The Avon Park Air Force Range (US Department of Defense) provided funding (Agreement W81XWH-04-2-0034). We thank P. Ebersbach for general support with this research, R. Crandall for installation of dendrometer bands at Avon Park Air Force Range and earlier analysis of dendrometer band data, and D. Ellair and C. Airey for assistance with data collection at Avon Park Air Force Range. We thank J. Isbell for installing dendrometer bands at St. Joseph Bay State Buffer Preserve. Analytical portions of this study were supported through National Science Foundation Awards DEB 0950302 and DEB 1556837 (W. Platt, principal investigator) and by Tall Timbers Research Station. Thank you to J. and P. Wade for establishing the Wade Tract research area. Thanks also to the Florida Forest Service (especially J. Saddler) for assistance in acquisition of lightning-fire data. Finally, thank you to the anonymous reviewers whose input greatly strengthened this manuscript. 


\section{LITERATURE CITED}

Ahlstrand, G.M. 1980. Fire history of a mixed conifer forest in Guadalupe Mountains National Park. USDA Forest Service General Technical Report RM-81, Rocky Mountain Forest and Range Experiment Station, Fort Collins, Colorado, USA.

Auchmoody, L.R. 1976. Accuracy of band dendrometers. USDA Forest Service Research Note NE-221, Northeastern Forest Experiment Station, Upper Darby, Pennsylvania, USA.

Baisan, C.H., and T.W. Swetnam. 1990. Fire history on a desert mountain range: Rincon Mountain Wilderness, Arizona, USA. Canadian Journal of Forest Research 20: 1559-1569. doi: 10.1139/x90-208

Beckage, B., W.J. Platt, M.G. Slocum, and B. Panko. 2003. Influence of the El Niño Southern Oscillation on fire regimes in the Florida Everglades. Ecology 84: 3124-3130. doi: 10.1890/02-0183

Benali, A., B. Mota, N. Carvalhais, D. Oom, L.M. Miller, M.L. Campagnolo, and J. Pereira. 2017. Bimodal fire regimes unveil a global-scale anthropogenic fingerprint. Global Ecology and Biogeography 26: 799-811. doi: 10.1111/geb.12586

Bowman, D.M.J.S., J. Balch, P. Artaxo, W.J. Bond, M.A. Cochrane, C.M. D’Antonio, R. DeFries, F.H. Johnston, J.E. Keeley, M.A. Krawchuk, C.A. Kull, M. Mack, M.A. Moritz, S. Pyne, C.I. Roos, A.C. Scott, N.S. Sodhi, and T.W. Swetnam. 2011. The human dimension of fire regimes on Earth. Journal of Biogeography 38: 2223-2236. doi: 10.1111/j. 1365-2699.2011.02595.x

Bowman, D.M.J.S., J.K. Balch, P. Artaxo, W.J. Bond, J.M. Carlson, M.A. Cochrane, C.M. D’Antonio, R.S. Defries, J.C. Doyle, S.P. Harrison, F.H. Johnston, J.E. Keeley, M.A. Krawchuk, C.A. Kull, J.B. Marston, M.A. Moritz, I.C. Prentice, C.I. Roos, A.C. Scott, T.W. Swetnam, G.R. van der Werf, and S.J. Pyne. 2009. Fire in the Earth system. Science 324: 481-484. doi: $10.1126 /$ science. 1163886

Caprio, A.C., and T.W. Swetnam. 1995. Historic fire regimes along an elevational gradient on the west slope of the Sierra Nevada, California. Pages 173-179 in: J.K. Brown, R.W. Mutch, C.W. Spoon, and R.H. Wakimoto, technical coordinators. Symposium on fire in wilderness and park management: past lessons and future opportunities. USDA Forest Service General Technical Report INT-GTR-320, Ogden, Utah, USA.

Clark, N.A., R.H. Wynne, and D.L. Schmoldt. 2000. A review of past research on dendrometers. Forest Science 46: 570-576.

Daubenmire, R.F. 1950. A comparison of season of cambial growth in different geographic races of Pinus ponderosa. Botanical Gazette 112: 182-188. doi: 10.1086/335646

Dieterich, J.H., and T.W. Swetnam. 1984. Dendrochronology of a fire-scarred ponderosa pine. Forest Science 30: 238-247.

Fill, J.M., W.J. Platt, S.M. Welch, J.L. Waldron, and T.A. Mousseau. 2015. Updating models for restoration and management of fiery ecosystems. Forest Ecology and Management 356: 5463. doi: 10.1016/j.foreco.2015.07.021

Florida Natural Areas Inventory. 2010. Guide to the natural communities of Florida, 2010 edition. <http://www.fnai.org/naturalcommguide.cfm>. Accessed 14 Jun 2017.

Fonda, R.W. 2001. Burning characteristics of needles from eight pine species. Forest Science 47: 390-396.

Fritts, H.C. 1976. Tree rings and climate. Academic Press, New York, New York, USA. 
Frost, C. 2006. History and future of the longleaf pine ecosystem. Pages 9-48 in: S. Jose, E.J. Jokela, and D.L. Miller, editors. The longleaf pine ecosystem: ecology, silviculture, and restoration. Springer, New York, New York, USA. doi: 10.1007/978-0-387-30687-2_2

Fulé, P.Z., M. Ribas, E. Gutiérrez, R. Vallejo, and M.W. Kaye. 2008. Forest structure and fire history in an old growth Pinus nigra forest, eastern Spain. Forest Ecology and Management 255: 1234-1242. doi: 10.1016/j.foreco.2007.10.046

Gaby, L.I. 1985. The Southern pines, an American wood. USDA Forest Service Report FS-256, Southeastern Forest Experiment Station, Athens, Georgia, USA.

Grissino-Mayer, H.D., W.H. Romme, M.L. Floyd, and D.D. Hanna. 2004. Climatic and human influences on fire regimes of the southern San Juan Mountains, Colorado, USA. Ecology 85: 1708-1724. doi: 10.1890/02-0425

Harley, G.L., H.D. Grissino-Mayer, J.A. Franklin, C. Anderson, and N. Köse. 2012. Cambial activity of Pinus elliottii var. densa reveals influence of seasonal insolation on growth dynamics in the Florida Keys. Trees 26: 1449-1459. doi: 10.1007/s00468-012-0719-2

Harley, G.L., H.D. Grissino-Mayer, and S.P. Horn. 2013. Fire history and forest structure of an endangered subtropical ecosystem in the Florida Keys, USA. International Journal of Wildland Fire 22: 394-404. doi: 10.1071/WF12071

Hayward, G.D., T.T. Veblen, L.H. Suring, and B. Davis. 2012. Challenges in the application of historical range of variation to conservation and land management. Pages $32-45$ in: J.A. Wiens, G D. Hayward, H.D. Safford, and C.M. Giffen, editors. Historical environmental variation in conservation and natural resource management. Wiley-Blackwell, West Sussex, England, United Kingdom. doi: 10.1002/9781118329726.ch3

Henderson, J.P. 2006. Dendroclimatological analysis of longleaf pine (Pinus palustris Mill.) in the Atlantic and Gulf Coastal Plain. Dissertation, University of Tennessee, Knoxville, Tennessee, USA.

Herrmann, V., S.M. McMahon, M. Detto, J.A. Lutz, S.J. Davies, C. Chang-Yang, and K.J. Anderson-Teixeira. 2016. Tree circumference dynamics in four forests characterized using automated dendrometer bands. PLoS ONE 11(12): 1-20. doi: 10.1371/journal.pone.0169020

Huffman, J.M. 2006. Historical fire regimes in Southeastern pine savannas. Dissertation, Louisiana State University, Baton Rouge, Louisiana, USA.

Huffman, J.M., W.J. Platt, H.D. Grissino-Mayer, and C.J. Boyce. 2004. Fire history of a barrier island slash pine (Pinus elliottii) savanna. Natural Areas Journal 24: 258-268.

Huffman, J.M., and M.T. Rother. 2017. Dendrochronological field methods for fire history in pine ecosystems of the Southeastern Coastal Plain. Tree-Ring Research 73: 42-46. doi: 10.3959/1536-1098-73.1.42

Keeland, B.D., and P.J. Young. 2014. Installation of traditional dendrometer bands. <https:// www.nwrc.usgs.gov/topics/Dendrometer/>. Accessed 3 Jun 2017.

Langdon, O.G. 1963. Growth patterns of Pinus elliotti var. densa. Ecology 44: 825-827. doi: 10.2307/1933044

Miles, P.D., and W.B. Smith. 2009. Specific gravity and other properties of wood and bark for 156 tree species found in North America. USDA Forest Service Research Note NRS-38, Northern Research Station, Newton Square, Pennsylvania, USA.

NCDC [National Climatic Data Center]. 2017. US Climate Divisions. <https://www.ncdc.noaa. gov/monitoring-references/maps/us-climate-divisions.php >. Accessed 2 February 2017.

Noss, R.F., W.J. Platt, B.A. Sorrie, A.S. Weakley, D.B. Means, J. Costanza, and R.K. Peet. 2015. How global biodiversity hotspots may go unrecognized: lessons from the North American Coastal Plain. Diversity and Distributions 21: 236-244. doi: 10.1111/ddi.12278 
Orzell, S.L., and E.L. Bridges. 2006. Floristic composition of the south-central Florida dry prairie landscape. Florida Ecosystem 1: 123-133.

Paul, B.H., and R.O. Marts. 1931. Controlling the proportion of summerwood in longleaf pine. Journal of Forestry 29: 784-796.

Pausas, J.G., J.E. Keeley, and D.W. Schwilk. 2017. Flammability as an ecological and evolutionary driver. Journal of Ecology 105: 289-297. doi: 10.1111/1365-2745.12691

Pausas, J.G., and D. Schwilk. 2012. Fire and plant evolution. New Phytologist 193: 301-303. doi: 10.1111/j.1469-8137.2011.04010.x

Platt, W.J. 1999. Southeastern pine savannas. Pages 23-51 in: R.C. Anderson, J.S. Fralish, and J.M. Baskin, editors. Savannas, barrens, and rock outcrop plant communities of North America. Cambridge University Press, England, United Kingdom. doi: 10.1017/ CBO9780511574627.003

Platt, W.J., S.M. Carr, M. Reilly, and J. Fahr. 2006. Pine savanna overstorey influences on ground-cover biodiversity. Applied Vegetation Science 9: 37-50. doi: 10.1111/j.1654-109X.2006.tb00654.X

Platt, W.J., D.P. Ellair, J.M. Huffman, S.E. Potts, and B. Beckage. 2016. Pyrogenic fuels produced by savanna trees can engineer humid savannas. Ecological Monographs 86: 352-372. doi: $10.1002 / \mathrm{ecm} .1224$

Platt, W.J., S.L. Orzell, and M.G. Slocum. 2015. Seasonality of fire weather strongly influences fire regimes in South Florida savanna-grassland landscapes. PLoS ONE 10(1): e0116952. doi: 10.1371/journal.pone.0116952

Pyne, S.J. 1982. Fire in America: a cultural history of wildland and rural fire. Princeton University Press, Princeton, New Jersey, USA.

Ryan, K.C., E.E. Knapp, and J.M. Varner. 2013. Prescribed fire in North American forests and woodlands: history, current practice, and challenges. Frontiers in Ecology and the Environment 11: e15-e24. doi: 10.1890/120329

Sakulich, J., and A.H. Taylor. 2007. Fire regimes and forest structure in a sky island mixed conifer forest, Guadalupe Mountains National Park, Texas, USA. Forest Ecology and Management 241: 62-73. doi: 10.1016/j.foreco.2006.12.029

Schweingruber, F.H. 1993. Trees and wood in dendrochronology: morphological, anatomical, and tree-ring analytical characteristics of trees frequently used in dendrochronology. Springer-Verlag, Berlin, Germany. doi: 10.1007/978-3-642-77157-6

Slocum, M.G., and S.L. Orzell. 2013. A structural equation model analysis of relationships among ENSO, seasonal descriptors and wildfires. PloS ONE 8: e75946. doi: 10.1371/journal. pone. 0075946

Slocum, M.G., W.J. Platt, B. Beckage, S.L. Orzell, and W. Taylor. 2010. Accurate quantification of seasonal rainfall and associated climate-wildfire relationships. Journal of Applied Meteorology and Climatology 49: 2559-2573. doi: 10.1175/2010JAMC2532.1

Slocum, M.G., W.J. Platt, B. Beckage, B. Panko, and J.B. Lushine. 2007. Decoupling natural and anthropogenic fire regimes: a case study in Everglades National Park, Florida. Natural Areas Journal 27: 41-55. doi: 10.3375/0885-8608(2007)27[41:DNAAFR]2.0.CO;2

Sorrie, B.A., and A.S. Weakley. 2001. Coastal Plain vascular plant endemics: phytogeographic patterns. Castanea 66: 50-82.

Speer, J.H. 2010. Fundamentals of tree-ring research. University of Arizona Press, Tucson, Arizona, USA. 
Stambaugh, M.C., J.M. Varner, and S.T. Jackson. 2018. Biogeography: an interweave of climate, fire, and humans. Pages 17-37 in: L.K. Kirkman and S.B. Jack, editors. Ecological restoration and management of longleaf pine forests. CRC Press, Boca Raton, Florida, USA.

Stambaugh, M.C., R.P. Guyette, and J.M. Marschall. 2011. Longleaf pine (Pinus palustris Mill.) fire scars reveal new details of a frequent fire regime. Journal of Vegetation Science 22: 1094-1104. doi: 10.1111/j.1654-1103.2011.01322.x

Stephens, S.L., C.N. Skinner, and S.J. Gill. 2003. Dendrochronology-based fire history of Jeffrey pine-mixed conifer forests in the Sierra San Pedro Martir, Mexico. Canadian Journal of Forest Research 33: 1090-1101. doi: 10.1139/x03-031

Stephens, S.L., M. Maier, L. Gonen, J.D. York, B.M. Collins, and D.L. Fry. 2018. Variation in fire scar phenology from mixed conifer trees in the Sierra Nevada. Canadian Journal of Forest Research 48: 101-104. doi: 10.1139/cjfr-2017-0297

Stokes, M.A., and T.L. Smiley. 1968. An introduction to tree-ring dating. University of Arizona Press, Tucson, Arizona, USA.

Thorne, R.F. 1993. Phytogeography. Pages 132-153 in: N.R. Morin, convening editor. Flora of North America north of Mexico. Oxford University Press, New York, New York, USA.

Vaganov, E.A., M.K. Hughes, and A.V. Shashkin. 2006. Growth dynamics of conifer tree rings: images of past and future environments. Springer-Verlag, Berlin, Germany.

Wahlenberg, W.G. 1946. Longleaf pine: its use, ecology, regeneration, protection, growth, and management. Charles Lathrop Pack Forestry Foundation, Washington, D.C., USA.

Weakley, A.S. 2015. Flora of the southern and mid-Atlantic states. University of North Carolina, Chapel Hill, North Carolina, USA.

White, C.R., and G.L. Harley. 2016. Historical fire in longleaf pine (Pinus palustris) forests of south Mississippi and its relation to land use and climate. Ecosphere 7: 1-17. doi: 10.1002/ ecs2.1458

Whitlock, C., P.E. Higuera, D.B. McWethy, and C.E. Briles. 2010. Paleoecological perspectives on fire ecology: revisiting the fire-regime concept. Open Ecology Journal 3: 6-23. doi: $10.2174 / 1874213001003020006$ 


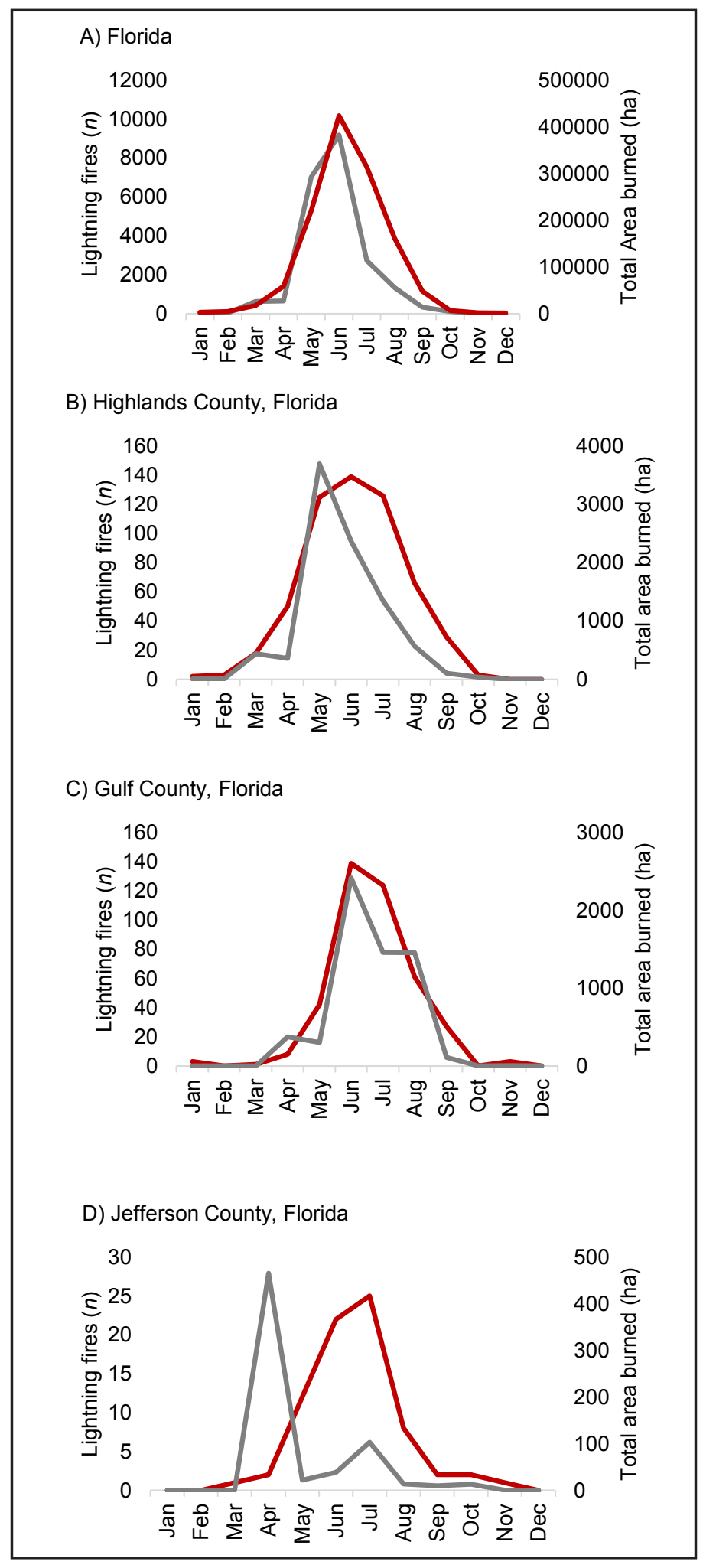

Supplementary Figure 1. Total lightning fires per month (n) compared to total area burned (ha) per month for the entire state of Florida (A) and for the counties of interest (B through D). Data are from the Florida Forest Service for the entire period of record (1981 to 2016). Please note that total area burned is plotted on a secondary $y$-axis. 
A)

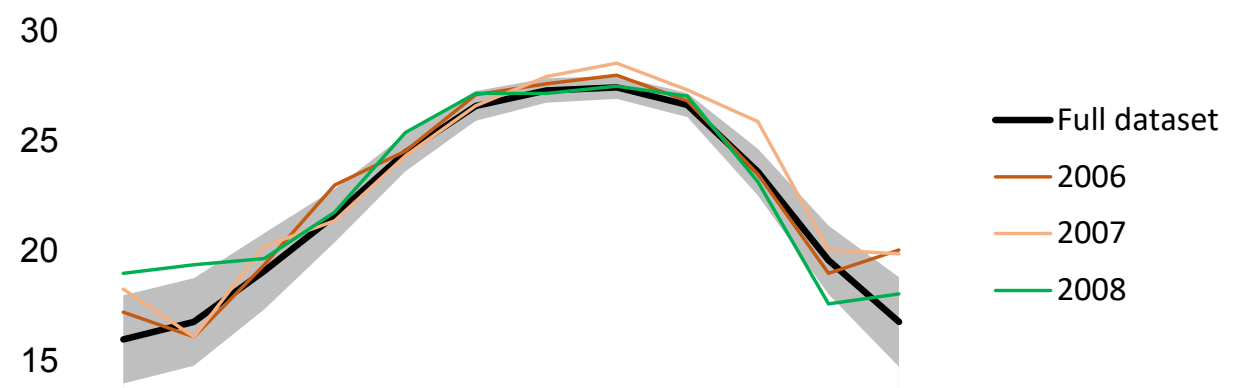

10

5

Jan Feb Mar Apr May Jun Jul Aug Sep Oct Nov Dec

B)

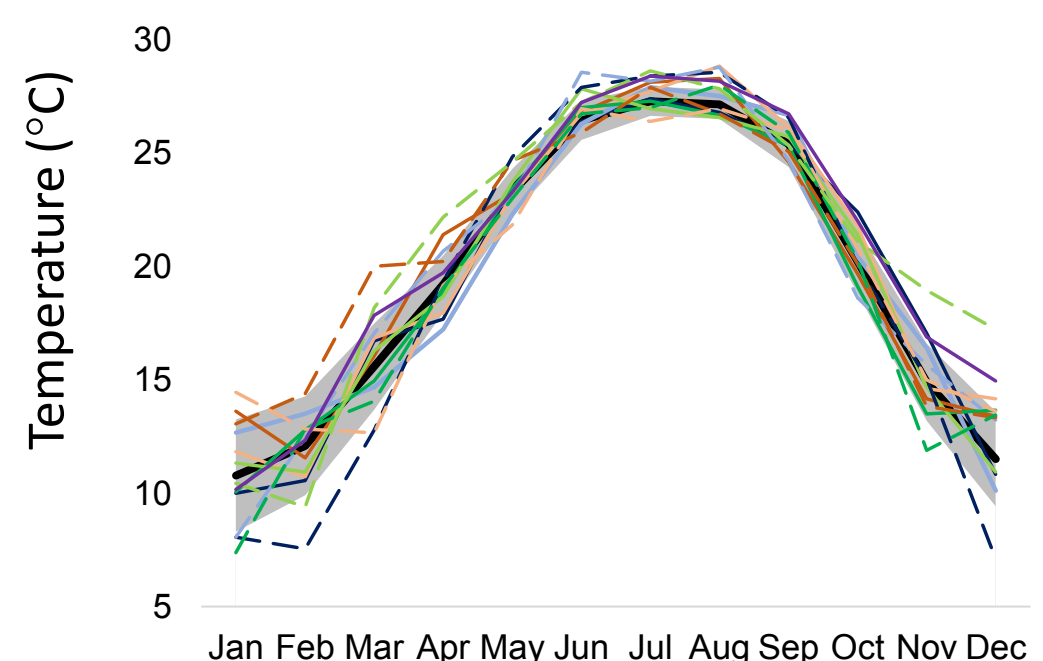

C)

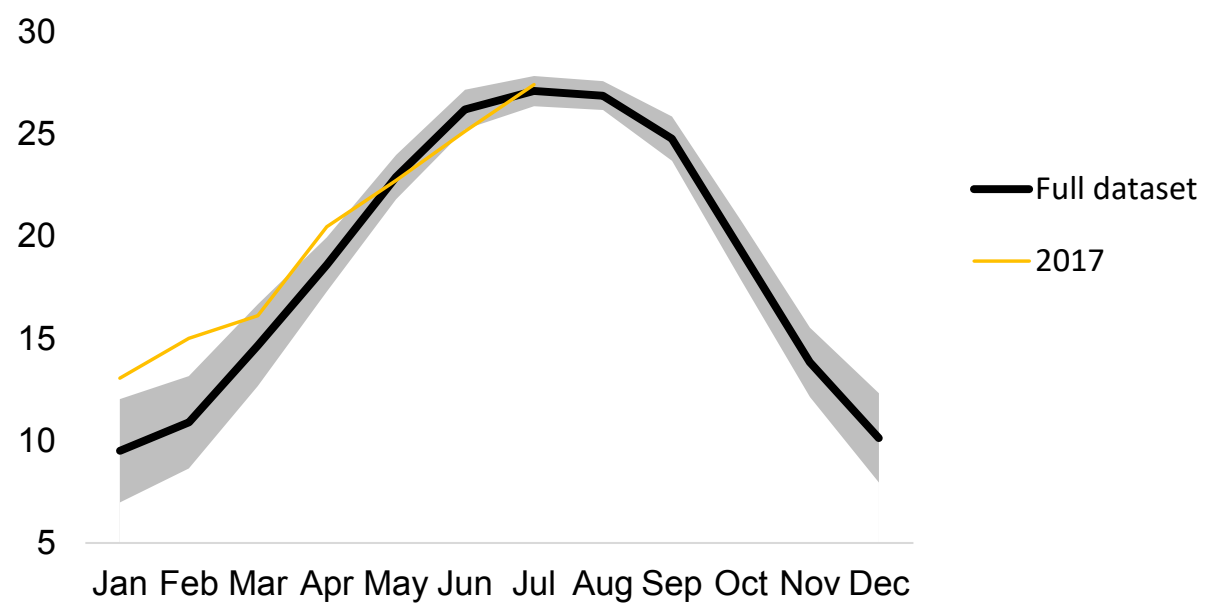

Supplementary Figure 2. Mean monthly temperature for the full dataset (1895 to 2016) compared to the years of data collection at: A) Avon Park, B) Buffer Preserve, and C) Wade Tract. The gray bands represent one standard deviation above and below the mean. 


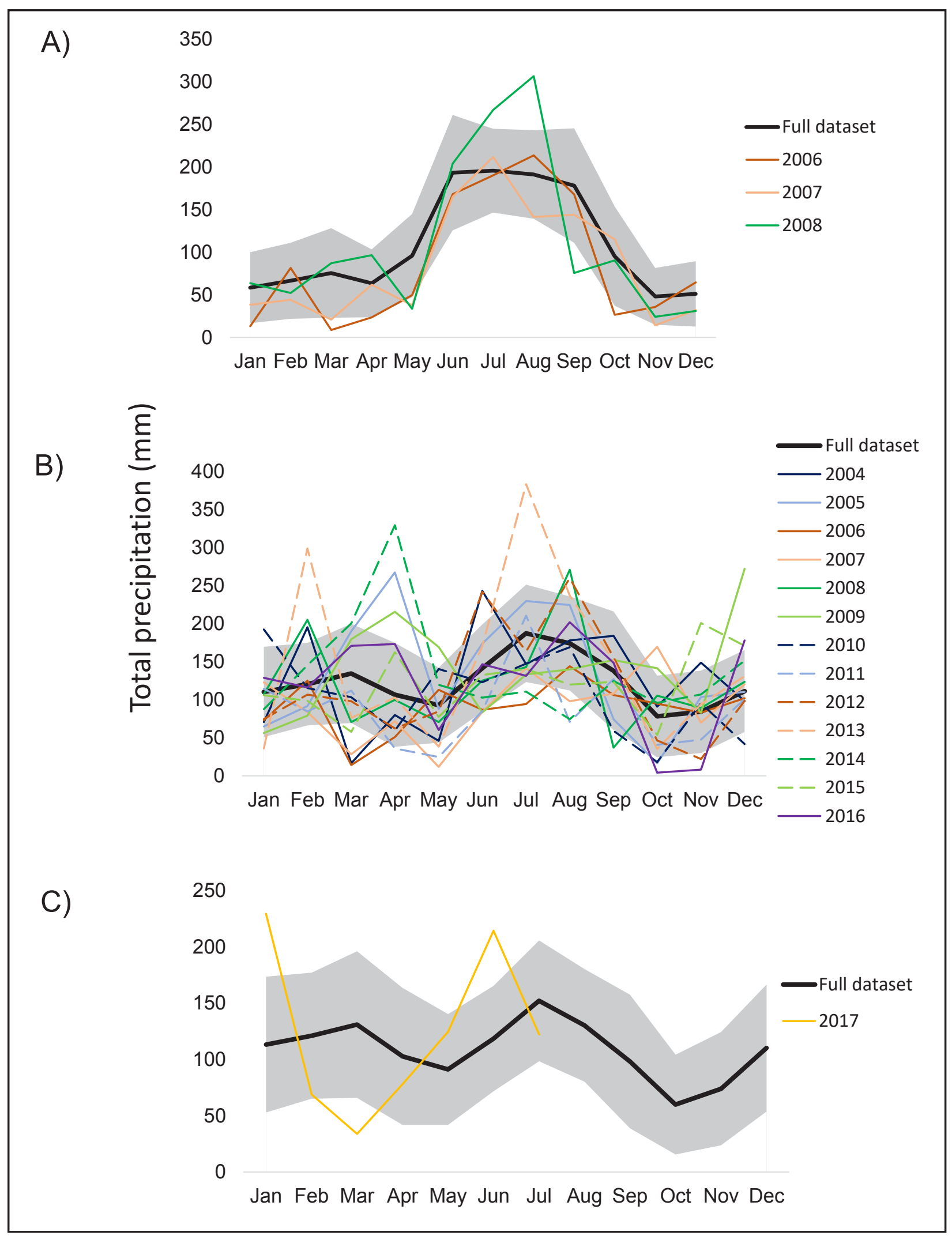

Supplementary Figure 3. Mean monthly total precipitation for the full dataset (1895 to 2016) compared to the years of data collection at A) Avon Park, B) Buffer Preserve, and C) Wade Tract. The gray bands represent one standard deviation above and below the mean. Please note that $y$-axes differ in total precipitation $(\mathrm{mm})$. 